REGARDS

SUR LEECONOMIE ALLEMANDE

BULLETIN ECONOMIQUE DU CRAC

\section{Regards sur l'économie allemande}

Bulletin économique du CIRAC

$114 \mid 2014$

Varia

\title{
Réseaux énergétiques
}

Dossier spécial - les réseaux de l'énergie, Politique Internationale

\section{OpenEdition}

\section{Journals}

Édition électronique

URL : http://journals.openedition.org/rea/4739

DOI : $10.4000 /$ rea.4739

ISSN : 1965-0787

Éditeur

CIRAC

Édition imprimée

Date de publication : 1 octobre 2014

Pagination : 44

ISSN : 1156-8992

Référence électronique

"Réseaux énergétiques », Regards sur l'économie allemande [En ligne], 114 | octobre 2014, mis en ligne le 01 octobre 2014, consulté le 22 septembre 2020. URL : http://journals.openedition.org/rea/4739 :

DOI : https://doi.org/10.4000/rea.4739

Ce document a été généré automatiquement le 22 septembre 2020

(C) CIRAC 


\section{Réseaux énergétiques}

Dossier spécial - les réseaux de l'énergie, Politique Internationale

\section{RÉFÉRENCE}

CHEVALIER Jean-Marie (et al.), Dossier spécial - les réseaux de l'énergie, Politique Internationale, $\mathrm{n}^{\circ} 144$ - été $2014,407 \mathrm{p}$.

1 Dans ce dossier spécial de la revue Politique Internationale consacré aux réseaux de l'énergie (voir l'article d'U. Hansen dans ce numéro), les auteurs abordent les défis posés - en termes d'approvisionnement - par la transition énergétique au niveau européen, un article étant consacré à la politique menée par l'Allemagne en la matière. L'ensemble met en évidence le besoin urgent de nouvelles capacités d'interconnexion en Europe. (Solène Hazouard) 